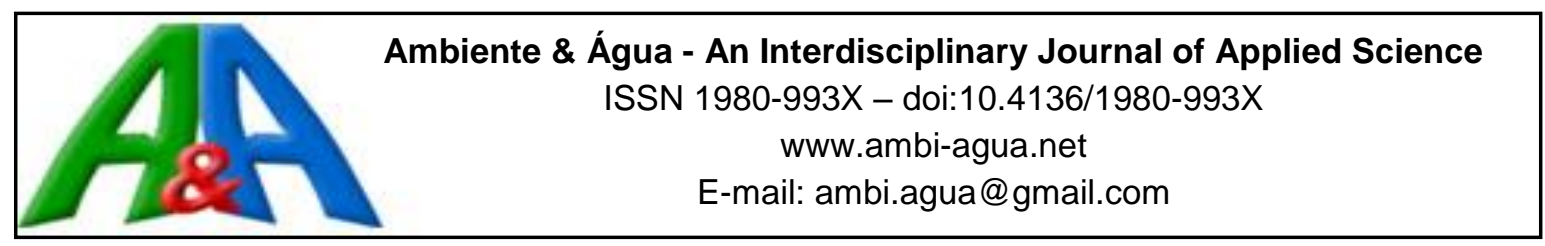

\title{
Effect of the riparian vegetation removal on the trophic network of Neotropical stream fish assemblage
}

\author{
ARTICLES doi:10.4136/ambi-agua.2088
}

Received: 31 Jan. 2017; Accepted: 12 Nov. 2017

\author{
Pedro Sartori Manoel; Virginia Sanches Uieda \\ Universidade Estadual Paulista "Júlio de Mesquita Filho" (UNESP), Botucatu, SP, Brasil \\ Departamento de Zoologia. E-mail: pedrosartori.bio@gmail.com, vsuieda@gmail.com \\ *Corresponding author
}

\begin{abstract}
The study of the diet of fish is an important tool to assess different levels of environmental degradation, since the availability of food in the environment is a key factor for the fish occurrence. The removal of riparian vegetation usually degrades environmental quality, as this vegetation has an important role in providing energy to the ecosystem. This study investigates the effects of the removal of riparian vegetation on the fish assemblage trophic network. The study was carried out in two stretches of a southeastern Brazilian stream, one in a forest fragment and another in a pasture, during the wet and dry seasons of 2014. We analyzed the items consumed by each fish species using the frequency of occurrence and area of each item, which were combined to calculate the alimentary index, which was used to determine the food niche overlap of the fish and the specialization index of the trophic network. Aquatic Hexapoda, vegetal debris and organic matter dominated the trophic network of the two stretches. We detected higher values of food niche overlap in the forested stretch and more complex trophic networks in the pasture stretch. We found few seasonal variations in the items consumed and calculated indices in both stretches studied. The presence of grass on the banks in the pasture stretch and the importation of food resources from the upstream area may have provided a higher diversity of resources and consequently showed a more complex trophic network when compared to the forested stretch.
\end{abstract}

Keywords: fish diet, food niche overlap, trophic organization.

\section{Efeito da remoção da vegetação ripária sobre a rede trófica de uma assembleia de peixes de um riacho neotropical}

\section{RESUMO}

O estudo da alimentação de peixes é uma importante ferramenta para avaliar diferentes níveis de degradação ambiental, uma vez que a disponibilidade de alimentos no ambiente é um fator-chave para a ocorrência de peixes. A remoção da vegetação ripária geralmente causa uma grande perda de qualidade ambiental, uma vez que essa vegetação tem um importante papel em gerar energia para o ecossistema. Nós investigamos os efeitos da remoção da vegetação ripária sobre a rede trófica das assembleias de peixes. Nosso estudo foi conduzido em dois trechos de um riacho do sudeste brasileiro, um em um fragmento florestal e outro em uma pastagem, durante as estações chuvosa e seca de 2014. Analisamos os itens consumidos por cada espécie 
de peixe utilizando a frequência de ocorrência e a área de cada item, que foram combinados para o cálculo do índice alimentar, o qual foi utilizado para determinar o valor médio da sobreposição de nicho alimentar da assembleia e o índice de especialização da rede trófica. As redes tróficas dos dois trechos foram dominadas por Hexapoda aquáticos, detritos vegetais e matéria orgânica. Observamos maiores valores de sobreposição de nicho alimentar no trecho florestado e redes tróficas mais complexas no trecho de pastagem. Verificamos poucas variações sazonais nos itens consumidos e índices calculados em ambos os trechos estudados. A presença de capim nas margens do trecho de pastagem e a importação de recursos alimentares da área à montante pode ter oferecido uma maior diversidade de recursos e, consequentemente, a assembleia de peixes apresentou rede trófica mais complexa quando comparada ao trecho florestado.

Palavras-chave: dieta de peixes, sobreposição de nicho alimentar, organização trófica.

\section{INTRODUCTION}

The expansion of agriculture and urbanization are the main factors that affect the aquatic ecosystems in São Paulo State, the most developed of Brazil, especially with respect to riparian vegetation removal, siltation and contamination by domestic and industrial sewage (Casatti et al., 2009; Oyakawa and Menezes, 2011). Consequently, streams with pristine conditions or less impacted are extremely rare and restricted mainly to Conservation Units. (Oliveira et al., 2013).

The riparian vegetation removal causes severe degradation of streams' quality, mainly in headwater streams that are more linked to the terrestrial ecosystem (Pusey and Arthington, 2003; England and Rosemond, 2004). Several studies (Allan, 2004; Casatti et al., 2006; Casatti et al., 2012) have showed the importance of riparian vegetation to the physical structure of streams, which can favor the maintenance of environmental stability and provide nutrients used through the trophic chain. Also, Rezende and Mazzoni (2005) have showed that in streams with riparian vegetation the input of allochthonous matter can change seasonally, with a higher input of animal- and vegetal matter during the wet season.

Many studies (Bojsen and Barriga, 2002; Casatti, et al., 2012; Teresa and Casatti, 2012) have also showed the effects of riparian vegetation suppression on fish assemblage; i.e., it leads to their simplification, with a high dominance of tolerant species and loss of ecosystem services. Moreover, Casatti et al. (2015) have found that although environments without riparian vegetation may have higher richness and diversity of fish, they also have a high functional redundancy, mostly related to feeding. Those impacted environments are generally simpler, with high habitat homogenization and low allochthonous resources supply (Zeni and Casatti, 2014). For fish fauna, the decrease in the food supply may lead to local extinction of some specialist species and the dominance of generalist ones, which are able to alter their diet according to the most abundant resource in the environment (Casatti, et al., 2006; Ferreira et al., 2012; Rezende et al., 2013; Zeni and Casatti, 2014).

We aim to investigates the effects of riparian vegetation removal on the trophic network of fish assemblage. We hypothesize that areas with riparian vegetation have more complex and specialized trophic networks, due to the high allochthonous resources supply provided by this vegetation, which can be used directly or indirectly as food by fish fauna. We also expect to find higher consumption of allochthonous material in the wet season due to the loading of this material to the stream by washout. 


\section{MATERIALS AND METHODS}

We conducted the study in two third-order stretches of $75 \mathrm{~m}$ of Itaúna Stream, which belongs to the Médio Paranapanema River Basin and is located in São Paulo State, southeastern Brazil. Throughout its length, the Itaúna Stream flows through forested and pasture areas, which

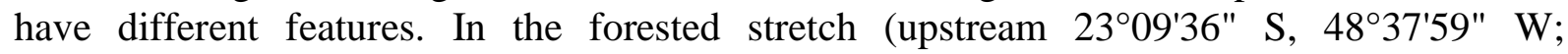
downstream $23^{\circ} 09^{\prime} 38^{\prime \prime} \mathrm{S}, 48^{\circ} 37^{\prime} 55^{\prime \prime} \mathrm{W}$ ), the stream runs through an extensive semi-deciduous forest fragment composed by primary vegetation with an approximate area of $790 \mathrm{~m}^{2}$ for $2.5 \mathrm{~km}$; the substrate is mainly composed of boulder, cobble and gravel, and has riffle, run and pool mesohabitats interspersed along its length. In this stretch, the average width is $4.5 \pm 1.3 \mathrm{~m}$ and the average depth is $0.2 \pm 0.1 \mathrm{~m}$. The pasture stretch (upstream $23^{\circ} 09^{\prime} 58^{\prime \prime} \mathrm{S}, 48^{\circ} 37^{\prime} 33^{\prime \prime} \mathrm{W}$; downstream $23^{\circ} 09^{\prime} 60^{\prime \prime} \mathrm{S}, 48^{\circ} 37^{\prime} 31^{\prime \prime} \mathrm{W}$ ) is located downstream and at a distance of $1 \mathrm{~km}$ from the forested one, and the stream runs for $3 \mathrm{~km}$ through an area without riparian vegetation and located in an extensive pasture area. This stretch is uniform, has a long run mesohabitat throughout its length; the substrate is composed mainly of sand, and grasses of Brachiaria genus that are partially submerged covering the banks. In this stretch, the average width is $2.1 \pm 1.2 \mathrm{~m}$ and the average depth is $0.3 \pm 0.1 \mathrm{~m}$. The transition area between the two stretches has riparian vegetation on one of the banks and pasture on the other.

We sampled the ichthyofauna along 80 meters on each stretch in the beginning of April and October of 2014, which represent the wet (previous month with rainfall of $185 \mathrm{~mm}$ ) and dry season (previous month with rainfall of $40 \mathrm{~mm}$ ), respectively.

We sampled the fish using two seine nets $(1 \times 4 \mathrm{~m}, 4 \mathrm{~mm}$ plastic mesh) that were arranged transversely in the stream, isolating upstream and downstream in a $2 \mathrm{~m}$ section. With the nets positioned, two samplers walked between them in the downstream direction, revolving the substrate and possible shelters to move and capture the fish in the downstream net. To standardize the catch effort, this procedure was repeated at least three times or until no individual was collected in this section. After this, we removed the downstream net and we reinstalled it $2 \mathrm{~m}$ above the upstream net, repeating the same procedure for the $75 \mathrm{~m}$ in each stretch. In pool areas, we installed two acrylic fish traps near the bank for three hours, with bread as bait; in places with grass in the banks we also used sieves (mesh $0.3 \mathrm{~cm}$ ) in the $2 \mathrm{~m}$ sections following the seine nets' standardization. For more details, see Uieda and Castro (1999).

For each stretch, we euthanized up to 15 individuals per species for diet analysis. Euthanasia was performed by immersion of fishes in a Eugenol solution (300 mg L-1). After death, we fixed the fishes in $10 \%$ formalin for 15 days and then we moved them to $70 \%$ alcohol. We deposited the fish collected in the Coleção de Peixes do Departamento de Zoologia e Botânica at the Universidade Estadual Paulista (UNESP), São José do Rio Preto, São Paulo, Brazil: DZSJRP 10101 to 10117 and DZSJRP 20455 to 20503.

In the laboratory, we removed the digestive tracts of the sampled specimens and analyzed the contents under stereomicroscope and microscope. We analyzed the stomach contents in species that have differentiated stomach or the initial intestine portion in the species that do not have differentiated stomach. Food items were classified as: organic matter (remains of decomposed undetermined live material); plant debris (pieces of leaves and roots); algae (filamentous and unicellular); terrestrial hexapods (larvae and adult hexapods of allochthonous origin); aquatic hexapods (larvae and adult hexapods of autochthonous origin); crustaceans, arachnids (aquatic mites); annelids (oligochaetes) and protozoa (testate amoebae). Aquatic hexapods were identified to the order level. For the diet analysis, we calculated the alimentary index (IAi), modified from Kawakami and Vazzoler (1980), which uses the occurrence frequency $(\mathrm{F})$ and the area $(\mathrm{A})$ through the formula $\mathrm{IAi}=(\mathrm{F} \times \mathrm{A}) / \Sigma(\mathrm{F} \times \mathrm{A})$. The frequency of occurrence (Hyslop, 1980) indicates the occurrence of the item, which is calculated as the 
number of fish with the item in relation to the total occurrences of all items. The area corresponds to the ratio between the area occupied by the item and the total area occupied by all items. Areas were measured using a glass slide placed on millimetric paper. To facilitate data presentation, we used acronyms for names of species and food items.

We defined the feeding habits of each species considering the items represented by more than $30 \%$ of IAi: a) algivorous - algae; b) carnivorous - items of animal origin; c) detritivorous - organic matter; d) insectivorous - aquatic and/or terrestrial insects; e) herbivorous - vegetal debris; f) omnivorous - plant and animal items; g) periphytivorous - algae and organic matter.

We created graphs of trophic interactions between fish species and the food items that they consumed in the "bipartite package" of R Cran Project software. With the IAi values, we also calculated the trophic specialization index $\left(\mathrm{H}^{2}\right)$ and the average percentage of dietary overlap $\left(\mathrm{H}^{\prime}\right)$ for each pair of species of each assemblage. The $\mathrm{H}^{2}$ is a two-dimensional index derived from the Shannon index used to compare different networks, and it ranges from 0 in extremely generalist communities to 1 in extremely specialist communities (Blüthgen et al., 2006). The $\mathrm{H}^{\prime}$ is the simple and most attractive measure of niche overlap which ranges from 0 in communities with no niche overlap to 100 in communities with total niche overlap (Krebs, 1989).

We used the diet of two generalist fish species sampled in both stretches and seasons (Astyanax bockmanni $\mathrm{n}=7$ in each sample, Phalloceros harpagos $\mathrm{n}=15$ in each sample) to verify if their diet varied spatial and temporally. It was assessed through a non-metric dimensional scaling ordination technique (NMDS), using the Bray-Curtis similarity index with area data of each individual. The statistical significance of the assemblage was tested through a similarity analysis (ANOSIM). In this analysis, if the " $R$ " value exceeds 0.25 , it indicates separated groups. We also performed a randomization process using Monte Carlo testing with 9999 interactions to validate the $R$ values observed. Values of $p<0.05$ indicate that the $R$ value observed was not randomly obtained. If significant differences were found, we also performed an analysis of similarity percentages (SIMPER) to verify which food items caused these differences. These analyses were performed using the software PRIMER 6.0.

\section{RESULTS AND DISCUSSION}

We sampled a total of 22 fish species, which belong to five orders and eight families (Table 1). The wet season of the pasture stretch showed the highest abundance and species richness, while the other three samples showed relatively similar richness and abundance values. 
Table 1. Total abundance of fish species sampled in the pasture and forest stretches of Itaúna Stream during the wet and dry seasons.

\begin{tabular}{|c|c|c|c|c|c|}
\hline \multirow{2}{*}{ Species } & \multirow{2}{*}{ Acronym } & \multicolumn{2}{|c|}{ Pasture Stretch } & \multicolumn{2}{|c|}{ Forested Stretch } \\
\hline & & Wet & Dry & Wet & Dry \\
\hline Astyanax altiparanae & Aalt & 2 & - & - & - \\
\hline Astyanax bockmanni & Aboc & 9 & 7 & 35 & 12 \\
\hline Astyanax fasciatus & Afas & 5 & 4 & - & - \\
\hline Bryconamericus iheringi & Bihe & 29 & 14 & 3 & 8 \\
\hline Bryconamericus stramineus & Bstr & 7 & - & - & - \\
\hline Cetopsorhamdia iheringi & Cihe & 2 & - & 3 & 2 \\
\hline Characidium gomesi & Cgom & 21 & 13 & 11 & 14 \\
\hline Characidium $\mathrm{sp}$ & Csp & - & 38 & 30 & 25 \\
\hline Characidium zebra & Czeb & 73 & - & 26 & 11 \\
\hline Eignmannia trilineata & Etri & - & - & - & 1 \\
\hline Geophagus brasiliensis & Gbra & 7 & 3 & - & - \\
\hline Hisonotos depressicauda & Hdep & 210 & 134 & 7 & 13 \\
\hline Hypostomus ancistroides & Hanc & 1 & 2 & - & - \\
\hline Hypostomus nigromaculatus & Hnig & - & - & 25 & 8 \\
\hline Imparfinis borodini & Ibor & - & - & 16 & 24 \\
\hline Imparfinis mirini & Imir & 26 & 28 & 1 & 1 \\
\hline Oligosarcus paranensis & Opar & 1 & - & - & - \\
\hline Paradon nasus & Pnas & - & 1 & - & - \\
\hline Phalloceros harpagos & Phar & 22 & 41 & 90 & 96 \\
\hline Phenacorhamdia tenebrosa & Pten & - & 1 & 3 & - \\
\hline Pimelodella gracilis & Pgra & 4 & 2 & - & - \\
\hline Rineloricaria pentamaculata & Rpen & 7 & 4 & 2 & 7 \\
\hline Abundance & & 426 & 292 & 252 & 222 \\
\hline Richness & & 16 & 14 & 13 & 13 \\
\hline
\end{tabular}

The overall diet analysis of all fish species sampled showed no major spatial and seasonal differences (Figure 1A). For the two stretches and seasons, there was a higher consumption of aquatic Hexapoda, followed by organic matter and vegetal debris. Regarding the different orders of aquatic hexapods (Figure 1B), in the two stretches and seasons there was a higher consumption of Diptera. However, there was variation in the second most consumed group, Trichoptera in the forested and Ephemeroptera in the pasture stretch. For the feeding habits (Figure 1C), the insectivorous predominated in both stretches and seasons. However, feeding habits occurred in the pasture stretch that did not occur in the forested stretch, like herbivorous in the two seasons and algivorous and carnivorous only in the dry season. 

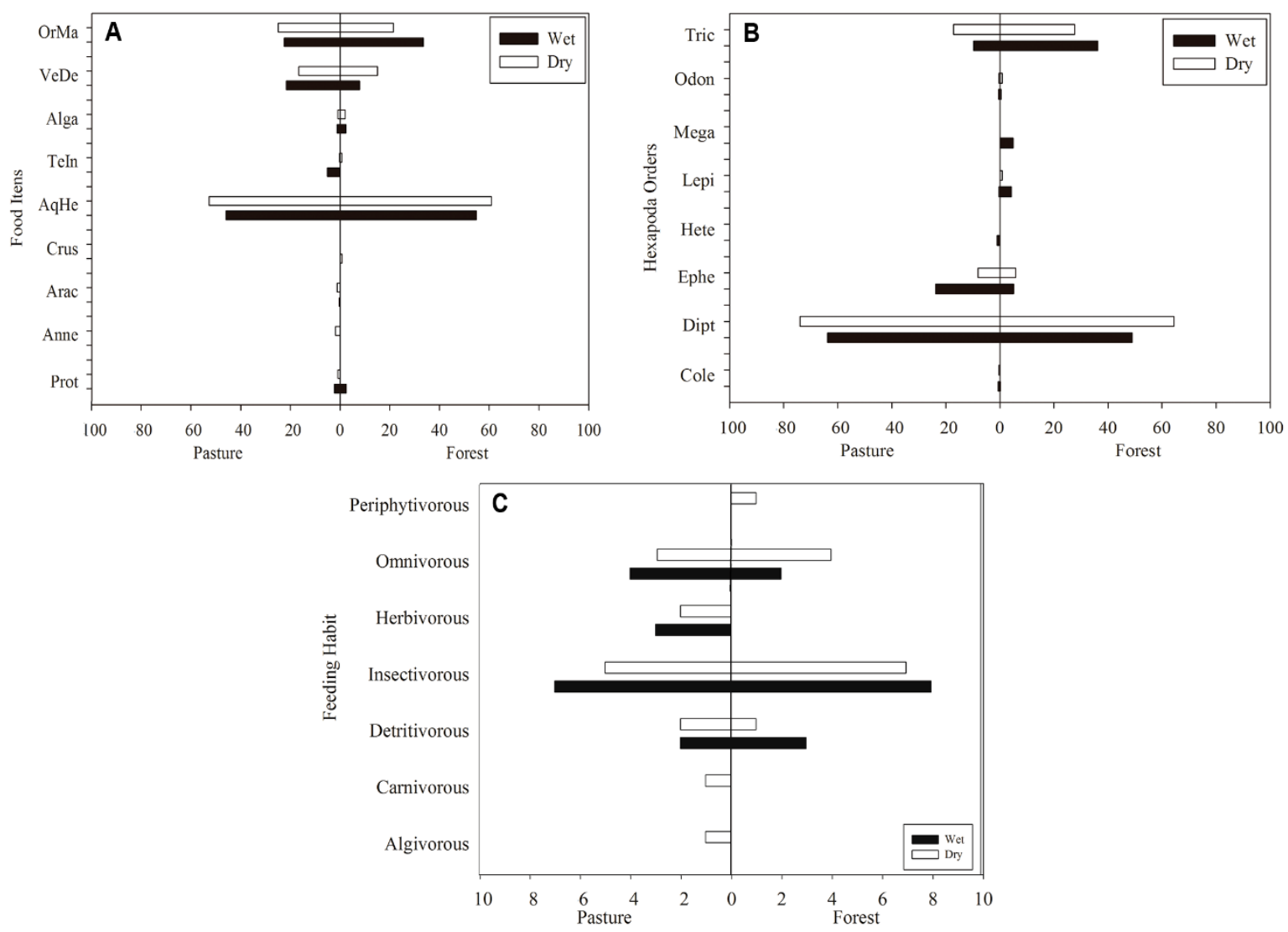

Figure 1. Percentage of consumption of food items (IAi\%) in the overall diet (A), consumption of aquatic hexapods orders (B), and number of feeding habits (C) of fish species sampled in the pasture and forest stretches of Itaúna Stream during the wet and dry seasons. OrMa=Organic Matter; VeDe=Vegetal Debris; Alga=algae; TeIn=Terrestrial Insects; AqHe=Aquatic Hexapoda; $\mathrm{Cru}=$ Crustacea; $\quad$ Arac $=$ Arachnida; $\quad$ Anne=Annelida; Prot=Protozoa; Tric $=$ Trichoptera; Odon=Odonata; Mega=Megaloptera; Lepi=Lepidoptera; Hete=Heteroptera; Ephe=Ephemeroptera; Dipt=Diptera; Cole=Coleoptera.

The trophic interaction networks showed higher complexity in the pasture stretch, with higher number of consumers and trophic interactions than in the forested stretch (Table 2, Figure 2). However, higher values of food niche overlap $\left(\mathrm{H}^{\prime}\right)$ and of community specialization $\left(\mathrm{H}^{2}\right)$ (Table 2) were observed in the forested stretch.

Table 2. Parameters of the trophic interaction networks built with the species of fish and the resources they consumed in Itaúna Stream during the wet and dry seasons of 2014. Cons consumers richness, Reso - number of consumed food resources, TI - number of trophic interactions, $\mathrm{H}^{\prime}$ - average values of food niche overlap, $\mathrm{H}_{2}$ - specialization index.

\begin{tabular}{lccccc}
\hline & Cons & Reso & TI & H' & $\mathbf{H}_{\mathbf{2}}$ \\
\hline Pasture-Wet & 16 & 6 & 30 & 32.6 & 0.629 \\
Pasture-Dry & 14 & 7 & 24 & 34.9 & 0.617 \\
Forest-Wet & 13 & 6 & 20 & 47.2 & 0.769 \\
Forest-Dry & 13 & 4 & 20 & 50.1 & 0.716 \\
\hline
\end{tabular}



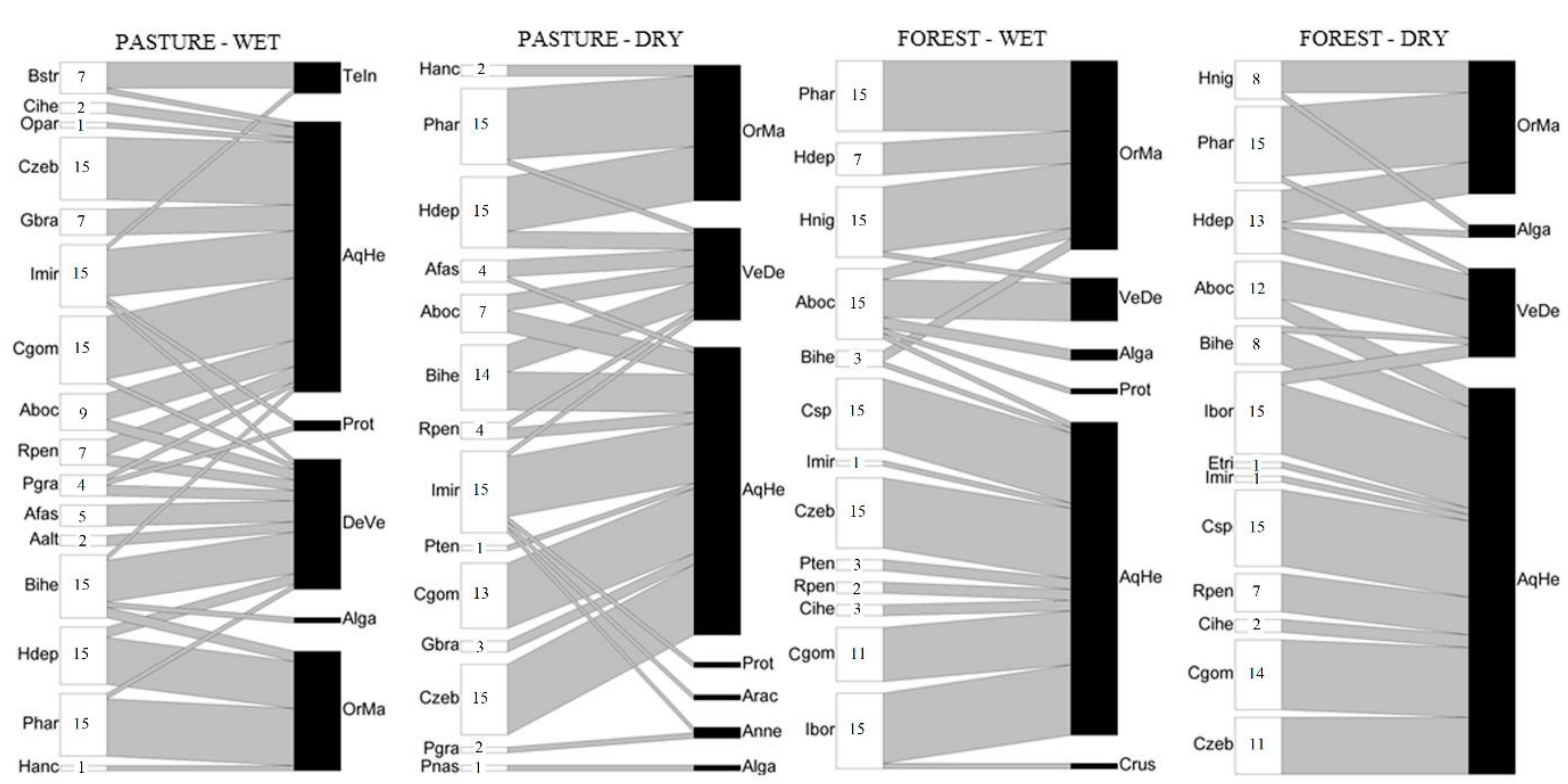

Figure 2. Graphs of trophic interactions in the pasture- and forest stretches of Itaúna Steam during the wet and dry seasons. White $=$ fish species with the number of analyzed specimens, black $=$ resources consumed, and gray $=$ trophic links. The height of the bars is proportional to the total values of number of gut contents analyzed (white) and IAi (gray and black). Acronyms of fish species in Table 1 and resources consumed in the caption of the Figure 1.

Although some authors (Agostinho et al., 2008; Zeni and Casatti, 2014) relate impacted environments with habitat simplification and homogenization, which would reduce the food resources supply to the fish fauna, Casatti et al. (2015) discuss that the presence of grass on the banks in pasture streams provides food resources such as leaves and roots and also retains organic matter. Moreover, they may also provide additional microhabitats used by macroinvertebrates that may serve as food for the fish fauna. Besides the presence of the vegetation on the banks, another factor that may have contributed to a more complex organization in the pasture stretch is its location downstream of the forested stretch. Upstream areas can export food resources such as vegetal debris, organic matter and terrestrial/aquatic insects that are carried by current to downstream areas where they can be metabolized (Lancaster et al., 1996; Webster et al., 1999). Therefore, the combination of these two factors, which provided a high food supply in the pasture stretch, was probably the cause of the largest number of feeding habits, the major number of trophic interactions, the lower niche overlap and trophic specialization found in this stretch.

The high consumption of aquatic insects and, consequently, the large number of insectivorous species observed in both stretches and seasons is common in tropical streams and also described by several authors (v. Casatti, 2002; Uieda and Motta, 2007; Bonato et al., 2012). Aquatic insects are an important food source for fish assemblages because they are extremely abundant and provide a large amount of protein (Ramos-Elorduy, 1997). However, the provision of that resource may change in composition and abundance depending on the physical features of the environment (Uieda and Pinto, 2011). This condition was observed between stretches where there was a higher consumption of Trichoptera in the forested stretch due to the bedrock and Ephemeroptera nymphs in the pasture due to the marginal grasses, where these two groups seek food and protection from predators (Mackay and Wiggins, 1979; Ferreira et al., 2015).

In the NMDS analysis, comparing the diet spatially and seasonally of the two generalist species, it was possible to observe differences only for A.bockmanni (Figure 3). The similarity analysis applied to the same data (ANOSIM) confirmed the differences for A.bockmanni, when seasons of forested stretch $(\mathrm{R}=0.45 ; \mathrm{p}=0.0006)$ were compared and when the two stretches 
in the wet season $(\mathrm{R}=0.62 ; \mathrm{p}=0.01)$ were compared. The SIMPER analyses showed that these differences were related mainly to the consumption of filamentous algae, high in the wet season of the forested stretch when compared to the dry season ( $28.98 \%$ of contribution), and high in the forest when compared stretches during the wet season (26.04\% of contribution). These differences could be related to the presence of the bedrock in this area. According to Rosemond (1993), some groups of algae grow attached to rocks at the bottom of streams and its growth mainly occurs in the wet season, when they have more nutrients and sunlight.

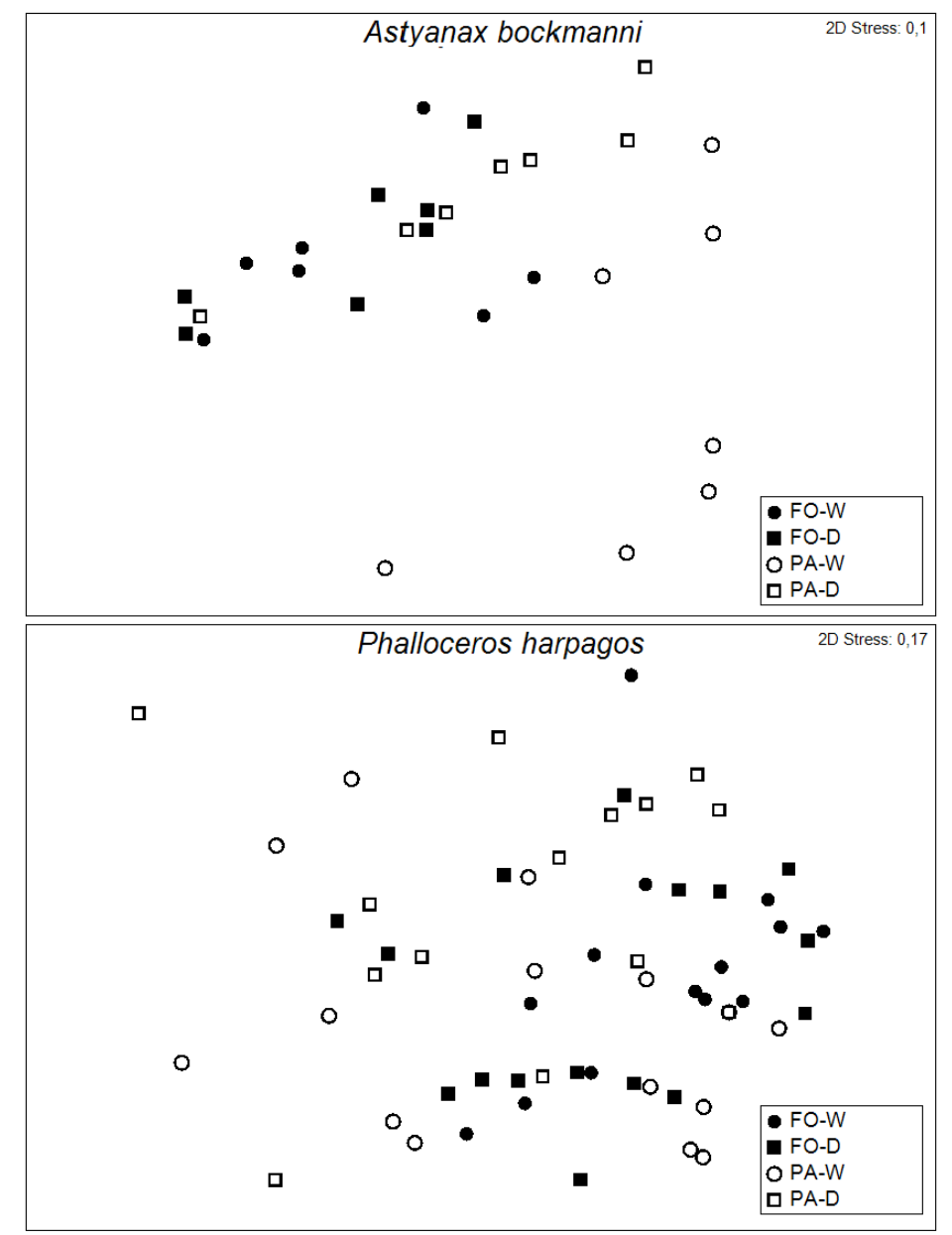

Figure 3. Results of the ordination analysis (NMDS) based on area data of each individual of two generalist fish species $(\mathrm{A}=$ Astyanax bockmanni, $\mathrm{B}=$ Phalloceros harpagos $)$, comparing the diet spatially (FO- forested stretch, PApasture stretch) and seasonally (W- wet season, D- dry season).

\section{CONCLUSIONS}

Although the pasture stretch does not have riparian vegetation, which provides food resources such as vegetal debris and organic matter, the presence of grass on the banks and the food resource carried downstream from the forested stretch provided a high resource diversity and, consequently, the fish fauna showed more complex trophic networks when compared to the forested stretch. 


\section{REFERENCES}

AGostinho, A. A.; PELICICE, F. M.; GOMES, L. C. Dams and the fish fauna of the Neotropical region: impacts and management related to diversity and fisheries. Brazilian Journal of Biology, v. 68.4, p. 1119-1132, 2008. http://dx.doi.org/10.1590/S151969842008000500019

ALLAN, J. D. Landscapes and riverscapes: The influence of land use on stream ecosystems. Annual Review of Ecology, Evolution and Systematics, v. 35, p. 257-284, 2004. http://dx.doi.org/10.1146/annurev.ecolsys.35.120202.110122

BLÜTHGEN, N.; MENZEL, F.; BLÜTHGEN, N. Measuring specialization in species interaction networks. Ecology, v. 6, p. 1-12, 2006. http://dx.doi.org/10.1186/1472-6785-6-9

BONATO, K. O.; DELARIVA, R. L.; SILVA, C. J. Diet and trophic guilds of fish assemblage in two streams with different anthropic impacts in the northwest of Paraná. Zoologia, v. 29, p. 27-38, 2012. http://dx.doi.org/10.1590/S1984-46702012000100004

BOJSEN, B. H.; BARRIGA, R. Effects of deforestation on fish community structure in Ecuadorian Amazon streams. Freshwater Biology, v. 47, p. 2246-2260, 2002. http://dx.doi.org/10.1046/j.1365-2427.2002.00956.x

CASATTI, L. Alimentação dos peixes de um riacho do Parque Estadual Morro do Diabo, Bacia do Alto Paraná, Sudeste do Brasil. Biota Neotropica, v. 2, p. 1-14, 2002. http://dx.doi.org/10.1590/S1676-06032002000200012

CASATTI, L.; FERREIRA, C. P.; CARVALHO, F. R. Grass-dominated stream sites exhibit low fish species diversity and dominance by guppies: an assessment of two tropical pasture river basins. Hydrobiologia, v. 632, p. 273-283, 2009. http://dx.doi.org/10.1007/s10750-009-9849-y

CASATTI, L.; LANGEANI, F.; SILVA, A. M.; CASTRO, R. M. C. Stream fishes, water and habitat quality in a pasture dominated basin, southeastern Brazil. Brazilian Journal of Biology, v. 66, p. 681-696, 2006. http://dx.doi.org/10.1590/S1519-69842006000400012

CASATTI, L.; TERESA, F. B.; GONÇALVES-SOUZA, T.; BESSA, E.; MANZOTTI, A. R.; GONÇALVES, C. S. et al.. From forests to cattail: how does the riparian zone influence stream fish? Neotropical Ichthyology, v. 10, p. 205-214, 2012. http://dx.doi.org/10.1590/S1679-62252012000100020

CASATTI, L.; TERESA, F. B.; ZENI, J. O.; RIBEIRO, M. D.; BREJÃO, G. L.; CENEVIVABASTOS, M. More of the same: High functional redundancy in stream fish assemblage from tropical agroecosystems. Environmental Management, v. 55, p. 1300-1314, 2015. http://dx.doi.org/10.1007/s00267-015-0461-9

ENGLAND, L. E.; ROSEMOND, A. D. Small reductions in forest cover weaken terrestrialaquatic linkages in headwater streams. Freshwater biology, v. 49, p. 721-734, 2004. http://dx.doi.org/10.1111/j.1365-2427.2004.01219.x

FERREIRA, C. P.; CASATTI, L.; ZENI, J. O.; CENEVIVA-BASTOS, M. Edge-mediated effects of forest fragments on the trophic structure of stream fish. Hydrobiologia, v. 762, p. 15-28, 2015. http://dx.doi.org/10.1007/s10750-015-2330-1 
FERREIRA, A.; DE PAULA, F. R.; FERRAZ, S. F. B.; GERHARD, P.; KASHIWAQUI, E. A. L.; CYRINO, J. E. P. et al. Riparian coverage affects diets of characids in neotropical streams. Ecology of Freshwater Fish, v. 21, p. 12-22, 2012. http://dx.doi.org/10.1111/j.1600-0633.2011.00518.x

HYSLOP, E. J. Stomach contents analysis-a review of methods and their application. Journal of Fish Biology, v. 17, p. 411-429, 1980. http://dx.doi.org/10.1111/j.1095-8649.1980.tb02775.x

KAWAKAMI, E.; VAZZOLER, G. Método gráfico e estimativa de índice alimentar aplicado no estudo de alimentação de peixes. Boletim do Instituto Oceanográfico, v. 29, p. 205 207, 1980. http://dx.doi.org/10.1590/S0373-55241980000200043

KREBS, C. J. Ecological methodology. New York: Harper \& Row, 1989. 654 p.

LANCASTER, J.; HILDREW, A. G.; GJERLOV, C. Invertebrate drift and longitudinal transport processes in streams. Canadian Journal of Fisheries and Aquatic Sciences, v. 53, n. 3, p. 572-582, 1996. https://dx.doi.org/10.1139/f95-217

MACKAY, R. J.; WIGGINS, G. B. Ecological Diversity in Trichoptera. Annual Review of Entomology, v. 24, p. 185-208, 1979.

OLIVEIRA, A. K.; APONE, F.; BIRINDELLI, J. L. O.; GARAVELLO, J. C. Fish assemblage structure of Ipanema River, a small lotic environment partially protected by a Conservation Unit in Southeastern Brazil. Brazilian Journal of Biology, v. 73, p. 259270, 2013. http://dx.doi.org/10.1590/S1519-69842013000200006

OYAKAWA, O. T.; MENEZES, N. A. Checklist dos peixes de água doce do Estado de São Paulo, Brasil. Biota Neotropica, v. 11, p. 1-13, 2011. http://dx.doi.org/10.1590/S1676-06032011000500002

PUSEY, B. J.; ARTHINGTON, A. H. Importance of the riparian zone to the conservation and management of freshwater fish: a review. Marine and Freshwater Research, v. 54, p. 1-16, 2003. http://dx.doi.org/10.1071/MF02041

RAMOS-ELORDUY, J. Insects: a sustainable source of food? Ecology of food and nutrition, v. 36, p. 247-276, 1997. http://dx.doi.org/10.1080/03670244.1997.9991519

REZENDE, C. F.; LOBÓN-CERVIÁ, J.; CARAMASCHI, E. P.; MAZZONI, R. Trophic ecology of two benthivorous fishes in relation to drift and benthos composition in a pristine Serra do Mar stream (Rio de Janeiro, Brazil). Fundamental and Applied Limnology/Archiv für Hydrobiologie, v. 183, p. 163-175, 2013. http://dx.doi.org/10.1127/1863-9135/2013/0430

REZENDE, C. F.; MAZZONI, R. Seasonal variation in the input of allochthonous matter in an Atlantic Rain Forest stream, Ilha Grande-RJ. Acta Limnologica Brasiliensia. v. 17, p. 167-175, 2005.

ROSEMOND, A. D. Interactions among irradiance, nutrients, and herbivores constrain a stream algal community. Oecologia, v. 94, n. 4, p. 585-594, 1993. http://dx.doi.org/10.1007/BF00566976

TERESA, F. B.; CASATTI, L. Influence of forest cover and mesohabitat types on functional and taxonomic diversity of fish communities in Neotropical lowland streams. Ecology of Freshwater Fish, v. 21, p. 433-442, 2012. http://dx.doi.org/10.1111/j.16000633.2012.00562.x 
UIEDA, V. S.; CASTRO, R. M. C. Coleta e fixação de peixes de riachos. Oecologia Australis, v. 6, p. 1-22, 1999.

UIEDA, V. S.; MOTTA, R. L. Trophic organization and food web structure of southeastern Brazilian streams: a review. Acta Limnologica Brasiliensia, v. 19, p. 15-30, 2007.

UIEDA, V. S.; PINTO, T. L. F. Feeding selectivity of ichthyofauna in a tropical stream: spacetime variations in trophic plasticity. Community Ecology, v 12, p. 31-39, 2011. http://dx.doi.org/10.1556/ComEc.12.2011.1.5

WEBSTER, J. R.; BENFIELD, E. F.; EHRMAN, T. P.; SCHAEFFER, M. A.; TANK, J. L.; HUTCHENS, J. J. et al. What happens to allochthonous material that falls into streams? A synthesis of new and published information from Coweeta. Freshwater Biology, v. 41, n. 4, p. 687-705, 1999. http://dx.doi.org/10.1046/j.1365-2427.1999.00409.x

ZENI, J. O.; CASATTI, L. The influence of habitat homogenization on the trophic structure of fish fauna in tropical streams. Hydrobiologia, v. 726, p. 259-270, 2014. http://dx.doi.org/10.1007/s10750-013-1772-6 